\title{
A conceptual model for driving green purchase among indian consumers
}

\author{
Prashant Trivedi \\ Research Scholar, \\ Department of Business Administration, \\ University of Lucknow, Lucknow \\ E-mail: prashant.5911@gmail.com
}

Received: 05.08.2015 / Revised: 08.12.2015 / Accepted: 10.12. 2015 / Published online: 30.12.2015

\begin{abstract}
Marketing is considered as responsible for increasing consumerism and overuse of limited resources. An endeavour to promote sustainable consumption is the need of the hour and an answer to growing concerns towards it is required. Marketing can be used as a tool to promote sustainability and increase responsible consumption. Many products which have energy saving potential can be successfully promoted through marketing activities. Increasingly, consumers are becoming aware about the issue and through constant marketing efforts green products and sustainable consumption can be taken to a high level. Contextual factors like value for money, features and selling point communication can play a crucial role in increasing the purchase of green products. Several studies are being conducted in this area but there is still a need for more research particularly in India. This paper will be a contribution to the existing area of knowledge and will focus on discovering the role which marketing can play in promoting sustainability among consumers in India. The factors which are responsible for sustainable consumption are explored and a conceptual model has been suggested which may help marketers in promoting green products and provide a platform for further research.
\end{abstract}

JEL classification: M00, M30, M31, Q50

Keywords: green purchase behaviour, sustainability, selling point, contextual factors

\section{INTRODUCTION}

Sustainability is an alarming issue in an emerging economy like India as the South Asian giant is on the verge of expanding its consumption to a higher level. As per a report of KPMG (2014), if it continues at the same growth rate, it will double its spending by 2025, with average household earning to triple in the next 20 years and consequently it may become the fifth largest consumer economy by 2025. Indian consumers are going through a transition stage, where they are exposed to a variety of products and services. Numerous brands are knocking at their doorsteps and positioning themselves in different ways. Indian consumers with majority of young population and rising disposable income are eager to make their lifestyle more and more comfortable. In 
a situation like this there is always a threat of over-consumption and consumerism is adding a flavour to it. Marketing in many ways has fuelled consumerism and made consumers realise some unique needs which they have never considered before.

The nature of Indian consumers is apparently price sensitive (Mukherjee et al., 2011), they are conscious of the price which they have to pay for the product they seek. So through marketing efforts and orientation from the initial stage like marketing research, the issue of pricing of a sustainable product shall be taken care of. Sustainability is a globally discussed issue and requires proper attention in the Indian context also. Previous researches have shown that consumers in India are aware about the concept of sustainability and there is a gap in concern and action. According to Greendex report (2014), consumers in participating countries including India have shown greater concern over environmental issues and believe that new technology can solve the environmental problem. There are many products available in the market which are comparatively better at saving energy and are less detrimental to the environment. There is a need for pulling consumers towards these products and through marketing activities this may become achievable. Marketing communication along with other complementing activities may positively position the pro-environmental products and boost their penetration in the form of increased sales which in return will reduce the consumption of energy and other limited resources.

In this paper we have taken variables like demography, psychography, awareness, intention, exposure to marketing communication, trust in green claims and reinforcement of the green issue at a point of purchase through salesmen along with clearance of doubts about the value for money, functional benefits of the product, advantages of the product over its non-green counterpart. The role of various factors which are crucial to driving green purchase is discussed.

\section{LITERATURE REVIEW}

The issue of sustainability is of growing concern. It is the need of the hour and if producers intend to blend environmentalism in successfully, then it should be in every aspect, be it designing of a product, manufacturing, delivery channels, usage, disposal, etc. (Ottman, 1992) Consumers' inclination towards environmentalism is more pronounced than before, consumers are interested in purchasing products which are environment-friendly (Krause, 1993). According to Elkington (1994), green consumers are the ones who avoid offerings which may adversely affect the health of the user.

The role of marketing in promoting sustainability can be very pronounced through proper understanding of consumers, their needs, demand, cost-benefit analysis, proper communication at various exposure points and especially at the point of purchase, where the salesperson can guide the customer about sustainability and its benefit and how one can help the cause through purchase of green products. The salesperson can make them realise the hedonic value of the product and imbibe the feeling of altruism also. They should also allay any apprehension over the green product in terms of its functionality and performance.

The pressure from the society is aligning companies towards sustainable behaviour (Ottman, 1992) The pressure created by this should not be ignored and green marketing can become one of the ways of answering the green concerns and promote sustainability. Companies can satisfy green consumers through proper marketing of green products (Polonsky, 1994). Green marketing includes all the functions which are taken by the marketing department to serve and satisfy the green consumer (Jain \& Kaur, 2004).

In order to serve the green customer in an effective manner proper understanding of their behaviour and attitude is required through segregating market into segments and then devising positioning strategies (Jain \& Kaur, 2004) which may serve as the initial steps towards sustainability. 


\section{Green Marketing}

Green marketing has been an important area in academic research. (Fuller, 1999; Ottman, 1998). Peattie (2001) suggested that evolution of green marketing was comprised of three phases, the "Ecological" green marketing phase was the first one and in this phase marketing activities were revolving around environmental problems and their solutions, after it came the second phase of "Environmental" green marketing where emphasis was on clean technology, improved designing and innovative products, to cope with problems like waste management, pollution, etc. And then the third phase was called as "Sustainable" green marketing which focuses on more comprehensive solutions. Increased environmental concern has resulted in the increase of challenges for companies (Johri \& Sahasakmontri, 1998). Sustainable or green marketing involves serving customers with good quality products offering standard performance and convenience at a lucrative price and which essentially work in a pro-environmental way (Dutta, 2009). For success of sustainability initiatives companies should believe and have confidence that green marketing can work and should make wise efforts to incorporate necessary product modifications, which not only deliver performance, but also are marketable.

\section{Green Consumption}

For the sake of green consumption a strong commitment towards environmental issues is required which may involve cost in terms of financial means and comfort from customers (Moisander, 2007) "Consumers looking to green their consumption are exposed to a wide number of environmental labels (Pedersen \& Neergaard, 2006; Hjalmarson et al., 2010), they may have to face the risk called as green washing (Peattie \& Crane, 2005) and keep themselves updated about the latest sustainability issues creeping up and have to cope with the ambiguity and uncertainty associated with green consumption (Halkier, 1999; Connolly \& Prothero, 2008). Green consumption in reality is challenging in terms of practicality and psychology; customers who want to become green may have to sacrifice some part of their comfort and style (Jonsson, 2006). Consumers turning towards sustainability should be committed to working harder than regular consumers and marketing efforts should help in finding more sustainable ways of consumption through offering green products.

\section{Green Consumer Satisfaction}

The contribution to the good of society through purchase of green products imbibes a feeling of satisfaction in customers (Montoro Rios et al., 2006). Sustainable behaviours from customers require some patience as they yield results in the long run rather than instant benefits but are good for the society as a whole (McCarty \& Shrum, 2001). When a customer purchases a green product he may do it out of altruism and feels a sense of accomplishment and well-being (Hoeffler \& Keller, 2002; Ritov \& Kahneman, 1997). The other benefit is a symbolic benefit, associated with the needs like external personal expression which is common in Indian consumers also. Consumers may not be interested in products which are unable to reflect their ideology (Montoro Rios et al., 2006) and consumers in India also seek products which can be an answer to their environmental concern, strengthen the feeling of altruism and deliver at par performance.

\section{Motivators for Green Consumers}

Many customers experience gratification when they are close to nature (Hartmann, Ibáñez, \& Sainz, 2005). This may be because of an emotional attachment and a feeling of freeness, safety and belonging with nature (Kals, Schumacher, \& Montada, 1999) "Also social approval seems to 
be an important factor in affecting green consumption but it is not the only driving force for taking voluntary actions that help to improve environmental quality and reduce environmental concern. A number of empirical studies also bring into light that environmental attitude of consumers related to the day to day behaviour is based on morality (Thøgersen 1999; Brul, Halvorsen, \& Nyborg, 2002; Guagnano, Stern, \& Dietz, 1995). For instance, Thøgersen (1999) pointed out that a majority of Danish consumers had developed personal norms for choosing environment-friendly packaging and these personal norms were the most important predictor of their probability to choose environment-friendly packaging. Likewise, in a survey conducted in Norway, (Brul, Halvorsen, \& Nyborg, 2002) suggested that many of respondents stated that they recycled mostly because they wanted to be portrayed as responsible people and that motivated customers for proenvironmental action (Whitmarsh \& O'Neill, 2010).

\section{Green Products}

Products can be classified on the basis of many characteristics like functions "utilitarian vs. hedonic" (Bridges \& Florsheim, 2008; Jones, Reynolds, \& Arnold, 2006) and involvement (low vs. high) (Bauer, Sauer \& Becker, 2006). Even the products can also be classified on the basis of their impact on the environment. All products are made of material and require energy in many ways, they excrete waste in the process of production and consumption also. However, some products have higher environmental impact and some have less. Several consumer behaviour scholars have pointed out that concern varies with the type of product (Babin, Darden, \& Griffm, 1994; Hirschman \& Holbrook, 1982). Thus, it is assumed that the concern associated with purchasing low environmental impact products, such as cereals or soya milk, may not be same as the feelings associated with purchasing high environmental impact items, like cars, batteries, or detergent. In reality, when consumers are going to buy a product and come to know that the product may be detrimental to the environment, they may begin to feel guilty.

\section{Green Advertising}

Previous studies have shown that effectiveness of advertising depends on how well the product matches with the real execution (Malhotra, 2005; Rossiter, Percy \& Donovan, 1991; Johar \& Sirgy, 1991). Rossiter et al. (1991) suggested that emotional advertising may work well in the case of low involvement or hedonic products. For products with the possibility of higher environmental impact, a message with green appeals probably has stronger effects than a message without green appeals. Therefore, the customers are more concerned for purchase of products which may impact the environment in an adverse manner (Henion, Russell, \& Clee, 1981). Laroche, Bergeron, \& Barbaro-Forleo (2001) found that it is possible that consumers may lack adequate knowledge of the causes and effects of environmental problems, and if presented with the same they may make pro-environment choices for products with high environmental concerns. Henion et al. (1981) emphasised that for consumers, ecological performance is more important and is ahead of functional performance and price in the case of products with higher negative effect on environment. It is also of vital importance that the weak connection between the green appeal and the product may lead consumers to mistake the green appeal as a green washing strategy adopted by the seller. If there is a gap in the promise and action customers may believe that they are deceived and it impedes the communication effectiveness in favour of green products (Chan \& Wong, 2006). 


\section{VARIABLES THAT MAY DRIVE CHOICE FOR SUSTAINABILITY}

\section{Demography}

The demographic profile of Indian consumers is very essential to be understood because previous studies have shown that various factors like age, income, education, gender, etc. are important in driving action towards sustainability.

\section{Education}

Previous researches have pointed out that education is an important factor for determining pro-environmental behaviour and found that there is a positive correlation between education and green consumer behaviour (Schwartz \& Miller, 1991).

Age

Most of the researches have shown that young and pre-middle age consumers are more inclined towards sustainability (Anderson \& Cunningham, 1977; Roberts \& Bacon, 1997).

\section{Gender}

Generally it is believed that probability of females being more environment conscious is high (Banerjee \& McKeage, 1994). Also, MacDonald \& Hara (1994) have found the relationship to be significant between gender and environment. On other hand, Samdahl \& Robertson (1989) have pointed out that the relationship between environmental concern and gender is insignificant. So this issue also requires proper attention for devising the right targeting strategy.

\section{Income}

In a country like India where consumers are very sensitive towards the price of a product, income plays an important role because with increasing income consumers may think of buying green products at a higher price. Zimmer (1994) found significant relationships between income and environmental attitudes and behaviour; on the other hand Roberts (1996) found no significant relationship between income and environmental concerns. In the Indian context income may be an important element which can play a crucial role in sustainable behaviour.

Straughan \& Roberts (1999) showed doubt over using demography alone as a variable for the segment of green consumers. Roberts (1996) also asserted that the demographic profile is not adequate for green consumer behaviour and marketers may identify and incorporate other variables like attitudes and behaviours, lifestyle, and purchase intentions in such studies.

\section{Values}

Values influence behaviour (McCarty \& Shrum, 1995), and consumers who buy environmentfriendly products are the ones who value the environment and understand the impact of their purchase on sustainability (Peattie, 2001). Consumers may realise that by purchasing an environmentally friendly product they can make a contribution to the cause of sustainability. A lower level of ecologically favourable behaviours may be because of a low level of selfinvolvement in protection of the environment (Wiener \& Sukhdial, 1990). Consumers can be motivated for sustainable purchases by making them realise the importance of the issue and the role which they can play (Bei \& Simpsons, 1995). Therefore, marketers should try to communicate to the consumers that purchase of green products can significantly impact the welfare of the environment and result in sustainability (Laroche et al., 2001). 


\section{Beliefs/Knowledge}

As far as impact of knowledge on sustainability is concerned, there are different views but in majority of researches, knowledge was found to be an important factor related to the purchase choice and evaluation (Alba \& Hutchinson, 1987). Knowledge is also a key predictor of sustainable behaviour (Vining \& Ebreo, 1990; Chan, 1999). As knowledge may influence all steps of the purchase decision, wrong information can lead consumers to make an imperfect choice. For example, most consumers in India are indifferent towards energy rating and they generally buy equipment with heavy energy consumption.

It has been a common argument that consumers perceive most recycled materials as of inferior quality when compared to non-recycled materials; consumers may perceive the performance of most recycled products below par with that of its non-recycled counterparts. Rao (1974) found customers are generally uncertain and sceptical about purchasing a green product if it is of poorer quality.

\section{Needs \& Motivations}

Many consumers' reports suggest that consumers are ready to spend extra for socially desirable products but actual purchase data in the Indian context reveals that sustainability in purchase means little. Therefore, companies are not very certain about consumers' responses to such surveys (Mainieri, Barnett, Valdero, Unipan, \& Oskamp, 1997). The probable reason for this may be "social over-reporting" of concern for environment (Peattie, 2001). Additionally, Hume (1991) concluded that consumers need not always act in line with their social reporting as far as environmental action is concerned and especially when purchasing a green product involves some sort of trade-off like paying a green premium, i.e. paying a higher price, choosing a lesser level of technical performance, visiting a non-standard retail outlet, etc. McCarty \& Shrum (1994) stated that inconvenience related with the product (its use, availability, etc.) also has an impact on consumers' action, which explains that any product which requires considerable amount of sacrifice despite being environment friendly may not succeed. It is evident from this that consumers generally are not interested in sacrificing comfort and quality lifestyle for sake of the environment and society.

\section{Attitude}

When we consider the effects of environmental attitudes on behaviour, findings suggest that attitudes are a very reliable and consistent predictor of green purchasing behaviours (Schlegelmilch, Greg, \& Diamantopoulos, 1996). Most of the studies have concluded that there is a positive correlation between concern (i.e. attitude) towards the environment and pro-environmental behaviour (van Liere, Dunlap Roberts \& Bacon, 1997). Simmons \& Widmar (1990) also found that in the case of recycling there is a significant relationship between concern and ecologically responsible behaviour. Berger \& Corbin (1992) found that behaviour of green consumers could be a result of their perceived notion (i.e. attitude) of the conservation of the environment. To further strengthen the finding regarding the impact of attitude on behaviour, researchers have suggested including multiple measures to increase the reliability of research outcome. Ajzen \& Fishbein (1977) have recommended to include other intervening variables, such as different attitude representations towards various objects. In addition, Weigel (1983) suggested incorporating situational or contextual factors to understand the relation between attitude and behaviour. Moreover, Straughan \& Roberts (1999) suggested that a mixed model incorporating a range of both demographics and psychographics should be preferred to the conventional demographic profiling methods in defining environmental behaviour as a function of environmental concern as psychographic variables may provide closer profiles of green consumers. 


\section{Intentions}

A consumer who is conscious of the environment will try to protect it in one way or another (Suchard \& Polonski, 1991). Therefore, there are different categories of eco-concerned consumers. A consumer who recycles aluminium may not be the same consumer who cares about recycling plastic or about air pollution. Intention is defined as a course of action that one intends to follow. It is believed that one who is purchasing a pro-environment product has an intention to buy it but several studies have shown a significant difference between intention and actual behaviour (Laroche, Toffoli, \& Muller, 1996).

\section{Eco-labelling}

Research has shown that consumers are not necessarily able to decipher the eco-labels attached to the products (Kangun \& Polonsky, 1995). Eco-labels like biodegradable, recyclable, fair wage/ fair trade, environment-friendly, and sustainable are usually unfamiliar /unknown to consumers. Moreover, recognising a label does not guarantee that one also understands its meaning and importance (Morris, Hastak, \& Mazis, 1995). Consumers are required to be able to decipher the information and trust the label before making purchasing decisions. Even the companies must remember that environmental labels can only work as a supplement for awareness and educational efforts for the environment and not as their substitute (Thogersen, 2000). Thus a comprehensive communication approach using clear eco-labels with a complementing smart salesman may help in educating consumers on the environmental impact of their purchasing decisions. Additionally, trust in green claims and label is very essential as consumer rely on the label only when it conveys trust.

\section{Consumer Backlash}

Studies have also found that many customers face difficulty in accepting products which claim to be environmentally safe and useful because of overemphasising the claim (Brown \& Wahlers, 1998). Inappropriate and unsubstantiated claims from companies have increased the cynicism about the products. Rousseau et al. (1998) emphasised that trust can be defined as the intention to accept vulnerability keeping in mind the positive expectations from the product, and trust may affect their decision to purchase (Gefen \& Straub, 2004). Messages based on facts, logic and representation of the actual benefit are more welcomed by customers and excessive claims increase the feeling of scepticism about the product.

\section{Role of Salesman}

Many researchers have argued for the inclusion of contextual factors, such as external drivers and barriers, when measuring pro-environmental behaviour, and this would probably have improved the explanatory power of the models further (McKenzie-Mohr, 2000; Stern, 2000). Contextual factors specific to a nation play an important role in affecting behaviour (Black et al., 1985); firms are required to devise comprehensive marketing strategies blending sustainability in at each step with inclusion of all the stakeholders like producer, salesman, distribution channel rather than going for green promotion alone (Polonsky et al., 1998). Salespeople can play a very vital role in developing and strengthening the buyer-seller relationship (Shepherd, 1999) as they are vested with the responsibility for making an initial contact with the customer, assessing his needs, and identifying products or services suiting his requirements and providing follow-up support and service (Pelham, 2002). Communication at the point of purchase with the help of the salesman may serve as a guide for green purchase and remove any cynicism regarding the product 
and claims as the salesman is in a better position to understand the psychology of the customer at the point of purchase, which can be a decisive factor in an emerging nation like India, as any confusion, doubt, apprehension can be removed and awareness about the green product can be increased, which may drive for green purchase. Moreover, merely copying models of researches based on high income, industrialised countries may not yield the desired result in emerging nations (Bodur \& Sarigöllü, 2005). Thus, marketers may design strategies which suit the Indian consumers and the marketing mix associated with it should reflect the same. Marketing with the help of integration of sustainability in every aspect can play a very vital role in converting the need for green products to want and the salesman can play a crucial role in directing green purchase.

\section{CONCEPTUAL FRAMEWORK}

Consumers' purchasing decisions on eco-friendly products which are helpful in promoting sustainability are influenced by many variables and a proposed model of how these variables affect purchase intentions and purchase decisions for environmentally friendly products is depicted below.

\section{Figure 1}

Conceptual model for green purchase in emerging nations

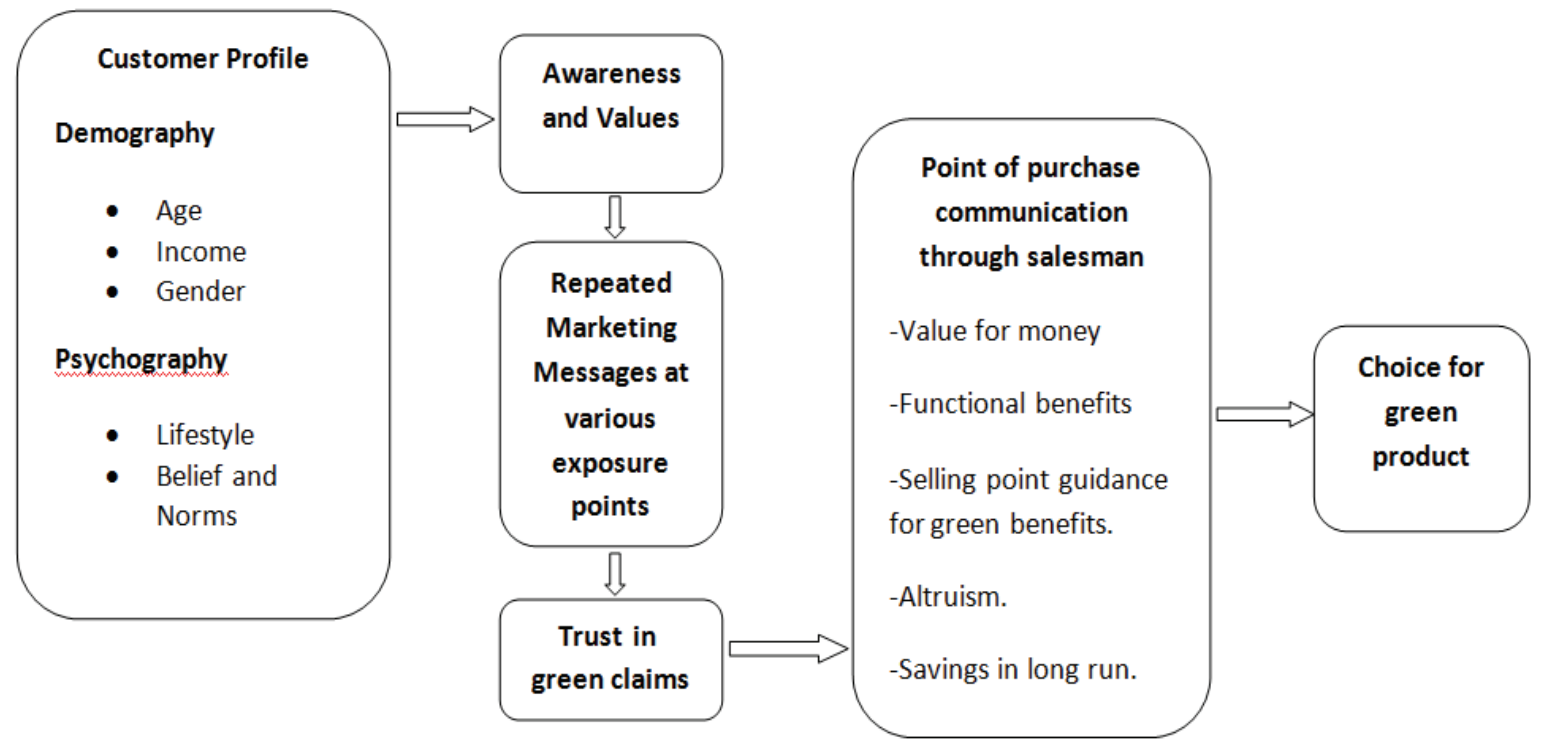

\section{Findings and Suggestions}

The findings in the form of conceptual model indicate that the role of marketing in green purchase decisions is crucial at every stage from product development to purchase. Through well planned and directed communication at various exposure points, marketers can increase the awareness about sustainability and benefits of green products, strengthen the trust in eco-friendly claims. Depending upon the profile of the customers, the salesman at the selling point can assess the needs of the customer and serve as a guide for a green product and the point of purchase can act as a classroom for consumer to learn and inquire about the green products where they can clear up their doubts regarding the product, compare it with the non-green substitute, learn about the reason for premium pricing (if any), long-term gain from its purchase, its features, performance 
and other aspects. The salesman can also imbibe a feeling of altruism among customers which may also become a factor driving them towards green purchase. The functional benefits and design of the product should be at par with customer expectations. Thus, thorough marketing efforts are required in promoting sustainability through green purchase choices. In light of these findings, we can say that marketing efforts in the right direction are helpful in promoting sustainability among Indian consumers and companies should make proper marketing efforts to promote green products and use factors like selling point communication, value for money, functional benefits of the product, altruism effectively in driving consumer towards green purchase choices and develop an edge in these aspects to lead towards better positioning of sustainable products, which may lead to repeating the purchase of green products in India.

\section{REFERENCES}

Ajzen, I. \& Fishbein, M. (1977) “Attitude-behaviour relations: A theoretical evaluation review of empirical research”, Psychological Bulletin, 84, pp. 888-918.

Anderson, T. Jr. \& Cunningham, W.H. (1972) “The socially conscious consumer”, Journal of Marketing, 36(7), pp. 23-31.

Andreoni, J. (1990) "Impure altruism and donations to public goods - a theory of warm-glow giving", Economic Journal, 100, pp. 464-77.

Babin, B.J., Darden, W.R. \& Griffin, M. (1994) "Work and/or fun: Measuring hedonic and utilitarian shopping value", Journal of Consumer Research, 20, pp. 644-656.

Banerjee, B. \& McKeage, K. (1994) "How green is my value: exploring the relationship between environmentalism and materialism”, in: Allen, C.T. \& John, D.R. (Eds), Advances in Consumer Research (pp. 147-52), Vol. 21, Provo, UT: Association for Consumer Research.

Bauer, H.H., Sauer, N.E. \& Becker, C. (2006) "Investigating the relationship between product involvement and consumer decision-making styles", Journal of Consumer Behaviour, 5(4), pp. 342-54.

Berger, I.E. \& Corbin, R.M. (1992) "Perceived consumer effectiveness and faith in others as moderators of environmentally responsible behaviours". Journal of Public Policy \& Marketing, 11(2), pp. 79-89.

Black, J.S., Stern, P. C. \& Elworth, J. T. (1985) "Personal and contextual influences on household energy adaptations", Journal of Applied Psychology, 70, pp. 3-21.

Bodur, M. \& Sarigöllü, E. (2005) "Environmental sensitivity in a developing country: consumer classification and implications", Environment and Behaviour, 37, pp. 487-510.

Brekke, K.A., Kverndokk, S. \& Nyborg, K. (2003) “An economic model of moral motivation”, Journal of Public Economics, 87(9/10), pp. 1967-83.

Bridges, E., \& Florsheim, R. (2008) "Hedonic and utilitarian shopping goals: The online experience", Journal of Business Research, 61(4), pp. 309-14.

Brown, J. \& Wahlers, R. (1998) "The environmentally concerned consumer: an exploratory study", Journal of Marketing Theory and Practice, 6(2), pp. 39-48.

Brul, A., Halvorsen, B. \& Nyborg, K. (2002) "Households' recycling efforts", Resources, Conservation and Recycling, 36(4), pp. 337-54.

Chan, R.Y.K., \& Wong, Y.H. (2006) "The effectiveness of environmental claims for services advertising", Journal of Services Marketing, 20(4), pp. 233-50.

Chen, Y.S, Lai, S.B. \& Wen, C.T. (2006) "The influence of green innovation performance on corporate advantage in Taiwan", Journal of Business Ethics, 67(4), pp. 331-339.

Connolly, J. \& Prothero, A. (2008) “Green consumption - Life-politics, risk and contradictions”, Journal of Consumer Culture, 8(1), pp. 117-45.

Dutta, B. (2009) "Sustainable green marketing — The new imperative", Marketing Mastermind, pp. 23-26.

Elkington, J. (1994) "Towards the sustainable corporation: Win business strategies for sustainable development", California Management Review, 36(2), pp. 90-100.

Fuller, D.A. (1999) Sustainable Marketing: Managerial-Ecological Issues, Thousand Oaks, CA: Sage Publications.

Gefen, D, \& Straub, D.W. (2004) "Consumer trust in B2C e-commerce and the importance of social presence: Experiments in e-products and e-service”. Omega 32(6), pp. 407-424.

Greendex (2014) Greendex 2014: Consumer Choice and the Environment-A Worldwide Tracking Survey. Retrieved from http://images.nationalgeographic.com/wpf/mediacontent/file/NGS_2014_Greendex_Highlights_ FINAL-cb1411689730.pdf. 
Guagnano, G.A., Stern, P.C. \& Dietz, T. (1995) "Influences on attitude-behaviour relationships - a natural experiment with curb side recycling”, Environment and Behaviour, 27, pp. 699-718.

Halkier, B. (1999) "Consequences of the Politicization of Consumption: The Example of Environmental Friendly Consumption Practices", Journal of Environmental Policy \& Planning, 1(1), pp. 25-41.

Hartmann, P., Ibáñez, A.V. \& Sainz, J.F.F. (2005) “Green branding effects on attitude: Functional versus emotional positioning strategies”, Marketing Intelligence and Planning, 23(1), pp. 21-30.

Henion, K.E., Russell, G. \& Clee, M.A. (1981) "Tradeoffs in attribute levels made by ecologically concerned and unconcerned consumers when buying washing powders", in: Monroe, K.B. (Ed.), Advances in consumer research (pp. 624-9), Vol. 8, Ann Arbor, MI: ACR.

Hirschman, E., \& Holbrook, M. (1982) "Hedonic consumption: Emerging concepts, methods and propositions", Journal of Marketing, 46, pp. 92-101.

Hjalmarson, H., Macquet, M. \& Sjöström, E. (2010) "Marketing to Consumers in Different Shades of Green: The Case of Chiquita Bananas/Rainforest Alliance”, in: Dobers, P. (Ed.) Corporate Social Responsibility: Challenges and Practices, Stockholm: Santérus Academic Press.

Hoeffler, S., \& Keller, K.L. (2002) Building brand equity through corporate societal marketing.

Jain, S.K. \& Kaur, G. (2004) "Green Marketing : An Indian Perspective”, Decision, 31(2), July-December, pp. 18-31.

Johar, J. \& Sirgy, J. (1991) "Value-expressive versus utilitarian advertising appeals: When and why to use which appeal", Journal of advertising, 20(3), pp. 23-33.

Johri, L.M. \& Sahasakmontri, K. (1998) "Green Marketing of Cosmetics and Toiletries in Thailand", Journal of Consumer Marketing, 15(3), pp. 265-81.

Jones, M.A., Reynolds, K.E. \& Arnold, M.J.(2006) "Hedonic and utilitarian shopping value: Investigating differential effects on retail outcomes", Journal of Business Research, 59(9), pp. 974-81.

Jonsson, P. (2006) Capturing the elusive simplifier. Göteborg: Center for Consumer Science.

Kals, E., Schumacher, D. \& Montada, L. (1999) "Emotional affinity toward nature as a motivational basis to protect nature", Environment and Behaviour, 31(2), pp. 178-202.

Kangun, N. \& Polonsky, M. (1995) "Regulation of environmental marketing claims: a comparative perspective", International Journal of Advertising, 11(1), pp. 1-24.

KPMG (2014) Indian retail: The next growth story. Retrieved from https://www.kpmg.com/IN/en/IssuesAndInsights/ ArticlesPublications/Documents/BBG-Retail.pdf. on 20 June 2015.

Krause, D. (1993) "Environmental consciousness: an empirical study”, J. Environ. Behav., 25(1), pp. 126-142

Laroche, M., Bergeron, J. \& Barbaro-Forleo, G. (2001) "Targeting consumers who are willing to pay more for environmentally friendly products", Journal of Consumer Marketing, 18(6), pp. 503-20.

Laroche, M., Toffoli, R., Kim, C. \& Muller, T.E. (1996) “The Influence of Culture on Pro-Environmental Knowledge, Attitudes, and Behaviour: A Canadian Perspective”, Advances in Consumer Research, 23, pp. 196 - 202.

Malhotra, K.N. (2005) "Attitude \& affect: New frontiers of research in the 21 st century", Journal of Business Research, 58(4), pp. 477-82.

MacDonald, W.L. \& Hara, N. (1994) Gender differences in environmental concern among college students, Sex Roles, 33(5/6), pp. 369-74.

McCarty, J. A. \& Shrum, L.J. (2001) "The influence of individualism, collectivism, and locus of control on environmental beliefs and behaviour", Journal of Public Policy \& Marketing, 20, pp. 93-104.

McCarty, J.A. \& Shrum, L.J. (1994) “The recycling of solid wastes: personal values, value orientations, and attitudes about recycling as antecedents of recycling behaviour", Journal of Business Research, 30(1), pp. 53-62.

McKenzie-Mohr, D. (2000) "Promoting sustainable behaviour: An introduction to community based social marketing”, Journal of Social Issues, 56, pp. 543-554.

Moisander, J. (2007) “Motivational complexity of green consumerism”, International Journal of Consumer Studies, 31, pp. 404-409.

Morris, L.A., Hastak, M. \& Mazis, M.B. (1995) “Consumer Comprehension of environmental advertising and labelling claims”, Journal of Consumer Affairs, 29, pp. 328-350.

Montoro Rios, F.J., Martinez, T.L., Moreno, F.F. \& Soriano, P.C. (2006) "Improving attitudes toward brands with environmental associations: An experimental approach”, Journal of Consumer Marketing, 23, pp. 26-33.

Mukherjee, A., Satija, D., Goyal, T.M., Mantrala, M.K. \& Zou, S. (2011) “Are Indian Consumers brand conscious? Insights for global retailers". Asia Pacific Journal of Marketing and Logistics, 24(3), 2012, pp. $482-499$.

Niva, M., Heiskanen, E. \& Timonen, P. (1997) “Consumers' environmental sophistication - knowledge, motivation and behaviour", European Advances in Consumer Research, 3, pp. 1-6.

Nyborg, K., Howarth, R.B. \& Brekke. K.A. (2006) "Green consumers and public policy: On socially contingent moral motivation”, Resource and Energy Economics, 28(4), pp. 351-66.

Ottman, J.A. (1992) Green Marketing. Chicago: NTC Business Books.

Ottman, J.A. (1998) Green Marketing: Opportunity for Innovation, New York, NY: NTC-McGraw-Hill.

Peattie, K. (2001) “Wards sustainability: The third age of green marketing”, Marketing Review, 2(2), pp. $129-146$. 
Pedersen, E. R. \& Neergaard, P. (2006) "Caveat Emptor - Let the Buyer Beware! Environmental Labelling and the Limitations of "Green” Consumerism", Business Strategy and the Environment, 15(1), pp. 15-29.

Pelham, A. M. (2002) “An Exploratory Model and Initial Test of the Influence of Firm-Level Consulting-Oriented Sales Force Programs on Sales Force Performance", Journal of Personal Selling and Sales Management, 22 (2), pp. 97-109.

Polonsky, M.J. (1994) “Green Marketing Regulation in the USA and Australia: the Australian Checklist”, Greener Management International, 5, January, pp. 44-52.

Polonsky, M.J., Roserberger, P.J. III \& Ottman, J. (1998) "Developing Green Product: Learning from Stakeholders", Asia Pacific Journal of Marketing and Logistics, 10(1), pp. 22-43.

Ritov, I. \& Kahneman, D. (1997) "How people value the environment: Attitudes versus economic values", in: Bazerman, M. (Ed.), Psychological perspectives to environmental and ethical issues.

Roberts, J.A. (1996a) "Will the real socially responsible consumers please step forward", Business Horizons, 39(1), pp. 79-84.

Roberts, J.A. (1996b), “Green consumers in the 1990s: profile and implications for advertising”, Journal of Business Research, 36(3), pp. 217-31.

Roberts, J.A. \& Bacon, D.R. (1997) "Exploring the subtle relationship between environmental concern and ecologically conscious consumer behaviour", Journal of Business Research, 40(1), pp. 79-89.

Rossitor, J.R., Percy, L. \& Donovan, R.J. (1991) “A Better Advertising Planning Grid”, Journal of Advertising Research, 31(5), pp. 11-21.

Rousseau, D.M., Sitkin, S., Burt, R.S. \& Camerer, C. (1998) "Not so different after all: A cross-discipline view of trust", Academy of Management Review, 23, pp. 393-404.

Samdahl, D.M. \& Robertson, R. (1989) "Social determinants of environmental concern: specification and test of the model", Environment and Behaviour, 21(1), pp. 57-81.

Schlegelmilch, B., Bohlen, G. \& Diamantopoulos, A. (1996) "The link between green purchasing decisions and measures of environmental consciousness", European Journal of Marketing, 30(5), pp. 35-55.

Schwartz, J. \& Miller, T. (1991) “The Earth's best friends. American Demographics”, 13(2), pp. 26-35. The Special Issue on Business and Management (C) Centre for Promoting Ideas, USA www.ijbssnet.com 196.

Simmons, D., \& Widmar, R. (1990) "Motivations and barriers to recycling: Toward a strategy for public education", The Journal of Environmental Education, 22, pp. 13-18.

Sheperd, C.D. (1999) "Service Quality and the Sales Force: A Tool for Competitive Advantage”, Journal of Personal Selling and Sales Management, 19 (3), pp. 73-82.

Shrum, L.J., McCarty, J.A. \& Lowrey, T.M. (1995) "Buyer characteristics of the green consumer and their implications for advertising strategy", Journal of Advertising, 24(2), pp. 71-90.

Stern, P.C. (2000) "Towards a coherent theory of environmentally significant behaviour", The Journal of Social Issues, 56, pp. 407-424.

Straughan, R.D. \& Roberts, J.A. (1999) "Environmental segmentation alternatives: a look at green consumer behaviour in the new millennium”, Journal of Consumer Marketing, 16(6), pp. 558-75.

Suchard, H.T. \& Polonski, M.J. (1991) "A theory of environmental buyer behaviour and its validity: the environmental action-behavior model”, in: Gilly, M.C. et al. (Eds), AMA Summer Educators' Conference Proceedings (pp. 187-201), Vol. 2, Chicago, IL: American Marketing Association.

Thøgersen, J. (1999) "Spill over processes in the development of a sustainable consumption pattern", Journal of Economic Psychology, 20, pp. 53-81.

Thogersen, J. (2000) Psychological Determinations of Paying Attention to Eco-labels in purchase decisions, Journal of Consumer Policy, 23 (3), pp. 285-315.

van Liere, K. \& Dunlap, R. (1981) “The social bases of environmental concern: a review of hypotheses, explanations, and empirical evidence", Public Opinion Quarterly, 44(2), pp. 181-97.

Weigel, R.H. (1983) “Environmental psychology”, Directions and perspectives (pp. 257-287), New York: Praeger.

Whitmarsh, L., \& O’Neill, S. (2010) “Green identity, green living? The role of pro-environmental self-identity in determining consistency across diverse pro-environmental behaviours", Journal of Environmental Psychology, 30(3), pp. 305-14.

Wicker, A.W. (1969) "Attitude versus actions: the relationship of verbal and overt behavioural responses to attitude objects", Social Issues, 25, pp. 41-78.

Zimmer, M.R., Stafford, T.F. \& Stafford, M.R. (1994) “Green issues: dimensions of environmental concern”, Journal of Business Research, 30(1), pp. 63-74. 